\title{
Industrial Fungal Enzymes: An Occupational Allergen Perspective
}

\author{
Brett J. Green and Donald H. Beezhold \\ Allergy and Clinical Immunology Branch, Health Effects Laboratory Division, National Institute for Occupational Safety and Health, \\ Centers for Disease Control and Prevention, Morgantown, WV 26505-2888, USA
}

Correspondence should be addressed to Brett J. Green, dox6@cdc.gov

Received 25 February 2011; Accepted 30 March 2011

Academic Editor: Gordon L. Sussman

Copyright ( $) 2011$ B. J. Green and D. H. Beezhold. This is an open access article distributed under the Creative Commons Attribution License, which permits unrestricted use, distribution, and reproduction in any medium, provided the original work is properly cited.

\begin{abstract}
Occupational exposure to high-molecular-weight allergens is a risk factor for the development and pathogenesis of IgE-mediated respiratory disease. In some occupational environments, workers are at an increased risk of exposure to fungal enzymes used in industrial production. Fungal enzymes have been associated with adverse health effects in the work place, in particular in baking occupations. Exposure-response relationships have been demonstrated, and atopic workers directly handling fungal enzymes are at an increased risk for IgE-mediated disease and occupational asthma. The utilization of new and emerging fungal enzymes in industrial production will present new occupational exposures. The production of antibody-based immunoassays is necessary for the assessment of occupational exposure and the development of threshold limit values. Allergen avoidance strategies including personal protective equipment, engineering controls, protein encapsulation, and reduction of airborne enzyme concentrations are required to mitigate occupational exposure to fungal enzymes.
\end{abstract}

\section{Introduction}

In the United States, the 2010 civilian workforce accounted for 139 million people [1] who spend up to a quarter of their lifetime and half of their waking lives at work [2]. With changes in the global market, particularly with the rise of biotechnology, new occupational hazards have emerged. Approximately, 200 biotic (organisms or particles of viral, prokaryote, or eukaryote origin) and an even greater number of abiotic (physical and chemical) agents have been associated with adverse health outcomes. In certain occupational settings, particularly those engaged in handling purified microbial proteins in baking and manufacturing sectors, workers are at increased risk of becoming sensitized and developing respiratory disease.

Occupational asthma $(\mathrm{OA})$ is the most common respiratory disease reported in the workplace [3-8]. OA has been defined as either irritant induced or immune mediated $[6,7]$. Immunologically mediated $\mathrm{OA}$ accounts for approximately $90 \%$ of cases [9], but the severity of disease is dependent on the concentration, route, agent of exposure, and the latency period $[6,7]$. Both high- and low-molecular-weight antigens can induce $\mathrm{OA}$, but the immunological mechanisms are distinctly different. High-molecular-weight allergens are generally proteins that are greater than $5 \mathrm{kDa}$, and production of immunoglobulin $\mathrm{E}$ ( $\mathrm{IgE}$ ) results in the release of mediators from mast cells and eosinophils $[6,7]$.

More than 250 high-molecular-weight allergens that induce OA have been identified $[4,6,7]$. Many are derived from animals or plants, and exposure usually involves mixtures of many proteins $[4,6]$. Occupations where high-molecular-weight allergens have been characterized include seafood processing (tropomysin), dairy, poultry, citrus, greenhouse, baking, healthcare (latex), pharmaceutical (drugs), and detergent manufacturing (fungal enzymes) [6]. Some of the best examples of high-molecular-weight occupational allergens are the fungal enzymes. They are particularly suited for study because they are often used as purified preparations in baking, food, detergent, textile, and pharmaceutical industries $[6,10]$. In this paper, we will focus on the fungal enzymes as model high-molecularweight allergens in industrial settings and describe the main enzymes that have been associated with occupational sensitization and asthma. Identification of emerging fungal enzymes in manufacturing and biotechnology industries is discussed as well as new methods to detect and quantify 
TABLE 1: Fungal enzymes utilized in different industries and associations with occupational sensitization.

\begin{tabular}{|c|c|c|}
\hline \multirow{2}{*}{ Industry } & \multicolumn{2}{|c|}{ Fungal Enzyme } \\
\hline & Characterized occupational allergen & Uncharacterized occupational allergen \\
\hline Agriculture & Protease, lipase & \\
\hline Animal feed & $\begin{array}{l}\alpha \text {-amylase, cellulase, lipase, phytase, protease, and } \\
\text { xylanase }\end{array}$ & Beta-glucanase*, endo-xylanase \\
\hline $\begin{array}{l}\text { Pulp and paper } \\
\text { production }\end{array}$ & Cellulase, hemicellulase, lipase, and xylanase & $\begin{array}{l}\text { Esterase*, laccase, lignin peroxidase, manganese } \\
\text { peroxidase, pectinase*, and mannose }\end{array}$ \\
\hline Waste management & Lipase & $\begin{array}{l}\text { Esterase*, cytochrome } \mathrm{P} 450 \text {, laccase, lignin peroxidase, } \\
\text { manganese peroxidase, and monooxygenase }\end{array}$ \\
\hline Biotechnology & $\begin{array}{l}\alpha \text {-amylase, cellulase, glucoamylase, hemicellulase, and } \\
\text { protease }\end{array}$ & $\begin{array}{l}\text { Cytochrome P- } 450 \text { monooxygenase, glucose oxidase, } \\
\text { glutathione-transferase*, lignin peroxidase, and } \\
\text { manganese peroxidase, }\end{array}$ \\
\hline Detergent & $\alpha$-amylase, cellulase, lipase, and protease & \\
\hline Food processing & $\begin{array}{l}\alpha \text {-amylase, cellulase, glucoamylase, lactase, lipase, } \\
\text { protease, and xylanase }\end{array}$ & Glucose isomerase, invertase, and pectinase* \\
\hline Biofuels & $\begin{array}{l}\alpha \text {-amylase, cellulase, glucoamylase, protease, and } \\
\text { xylanase }\end{array}$ & \\
\hline Bakery & $\begin{array}{l}\alpha \text {-amylase, cellulase, glucoamylase, hemicellulase, } \\
\text { lipase, protease, and xylanase }\end{array}$ & Glucose oxidase, lipoxygenase \\
\hline $\begin{array}{l}\text { Brewing and wine } \\
\text { production }\end{array}$ & Cellulase, glucosidase, protease, and xylanase & $\begin{array}{l}\text { Alpha-acetolactate decarboxylase, beta-glucanase*, and } \\
\text { pectinase* }^{*}\end{array}$ \\
\hline Pharmaceutical & Lactase, lipase, and protease & $\begin{array}{l}\text { Alpha-galactosidase*, catalase*, cytochrome } \mathrm{P} 450 \\
\text { oxygenase, and glutathione transferase* }\end{array}$ \\
\hline Textile & $\alpha$-amylase, cellulase, lipase, protease, and xylanase & Catalase* $^{*}$ \\
\hline Leather processing & Lipase, protease & \\
\hline Hygiene products & Glucoamylase, protease & Catalase, ${ }^{*}$ glucose oxidase \\
\hline
\end{tabular}

Adapted from Baur [10] and from the Concordia University Genomics Project website: https://fungalgenomics.concordia.ca/home/indappl.php.

*Denotes fungal enzymes associated with allergic sensitization in other fungal bioaerosols or environmental allergens.

fungal enzymes in the occupational environment. Methods to avoid fungal allergens in the workplace are additionally covered.

\section{Fungal Enzymes in Occupational Disease}

The industrial utility of fungi has been well known since antiquity. In addition to the role of fungi as saprophytes in the environment, many species have commercial use, for example, mushrooms as food sources, ingredients in food preparation (cheese flavoring Penicillium roqueforti), alcoholic fermentation, and the conversion of sugars in bread dough to carbon dioxide (Saccharomyces cerevisiae). In Asia, Aspergillus oryzae is an essential ingredient for the production of soy sauce and the fermented drink, sake. Rhizopus spp. secrete a wide variety of enzymes including cellulolytic, proteolytic, lipolytic, and pectinolytic enzymes that are used in the production of various foods such as Tempe from Indonesia [46]. Rhizopus oryzae has also been identified as a biocatalyst for biodiesel fuel production [47]. Other fungi such as Yarrowia lipolytica have more recent applications in the biodegradation of industrial products [48]. Advances in industrial enzymology following World War II have enabled researchers to identify and utilize various enzymes and proteases that fungi produce to break down carbohydrate and lignin containing plant material in the environment [49]. To date, close to 200 fungal enzymes have been purified from fungal cultures and the biochemical and catalytic properties characterized $[10,50]$. These enzymes have great utility in pharmaceutical, agricultural, food, paper, detergent, textile, waste treatment, and the petroleum industries.

Industrial fungal enzymes are high-molecular-weight proteins that are catalysts [10, 49]. A description of the common enzymes used in various industries is presented in Table 1. The most widely used enzymes of occupational importance are derived from the genus Aspergillus and include $\alpha$-amylase, xylanase, and cellulase. A summary of the proteomic and immunologic properties of these enzymes is presented in Table 2. Other enzymes are also utilized from rhizosphere fungal species belonging to the genera Rhizopus and Humicola (Table 2). These enzymes usually have intracellular or other functional roles associated with apical hyphal growth. It is uncommon for individuals in the general population to be exposed and sensitized to these antigens. In fact, in the general population, the prevalence of sensitization to fungal enzymes has been reported to be as low as $1 \%$ and as high as $15 \%[22,51]$. However, in the occupational environment, workers that handle purified fungal enzymes are at an increased risk of becoming sensitized to enzymes $[10,23,24,42,52-56]$. This is especially the case for workers whose occupation requires debagging, sieving, weighing, dispensing, and mixing enzymes [24, 53-56]. Eight-hour time-weighted average exposures demonstrate 


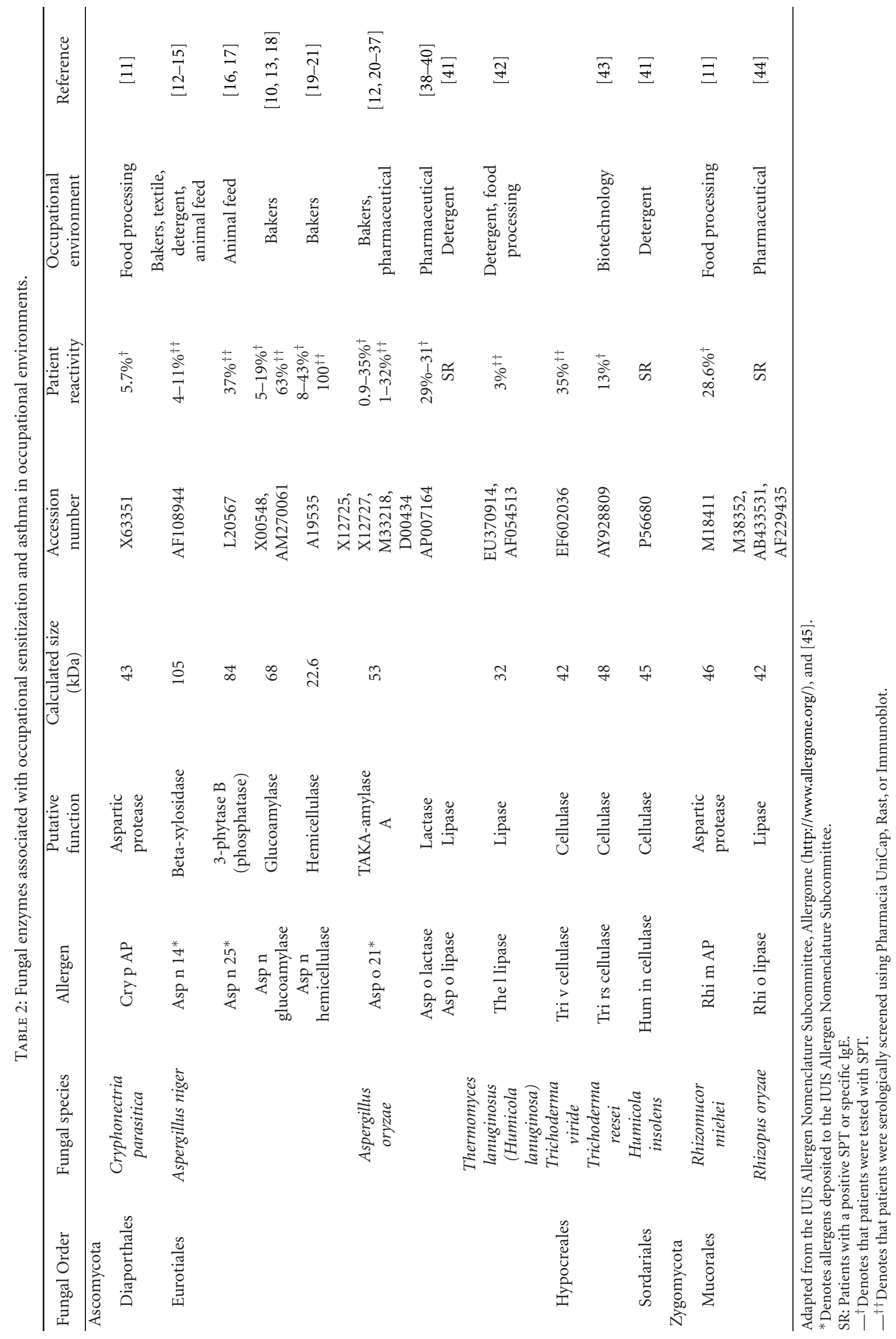


that occupations weighing the enzyme preparations have the lowest average exposure compared to those workers that sieve [24]. These workers are often exposed to levels of dust that exceed $4 \mathrm{mg} \mathrm{m}^{-3}$, the threshold limit value (TLV) for inhalable dust [57]. For other industrial environments that use lipase and cellulose in production, occupational exposure is highest in production areas and laboratories [42].

Adverse health effects associated with enzyme exposure are well characterized in the baking industry. In some countries, bakery exposures to enzymes are one of the leading causes of occupational allergy [58]. Fungal enzymes are commonly used as baking additives to improve the dough, increase shelf life, and decrease production time [19, 49, 59]. Airborne concentrations ranging from $5.3 \mathrm{ng} \mathrm{m}^{-3}$ to $200 \mathrm{ng} \mathrm{m}^{-3}$ have been reported in occupational environments $[12,59,60]$. Occupational sensitization to fungal enzymes was first reported by Flindt [61]. Later, Baur et al. [62] demonstrated IgE sensitization in workers handling these products. Since the original study, fungal enzymes have been identified as potent allergens in the occupational environment $[25,26]$. Prevalence of sensitization to Aspergillus enzymes ranges from 8\% for glucoamylase [13], $11 \%$ for xylanase [13], 13\% for cellulase [13], and up to $34 \%$ for $\alpha$-amylase $[19,27]$. Sensitization to $\alpha$-amylase in bakery workers results in decreased peak expiratory flow [63$66]$ and $\mathrm{OA}[20,28,67]$. In one report, workers exposed to fungal enzymes induced an immediate bronchospastic reaction [49]. In the United States, the prevalence of work-related wheeze, runny nose, frequent sneezing, and specific IgE to fungal enzymes was significantly higher among highly exposed workers [68]. However, other irritantinduced mechanisms associated with high total dust levels have also been reported in a cohort of British bakers $[29,56]$. To date, atopy has been hypothesized to be an important risk factor for OA to fungal enzymes.

Occupational exposure to enzymes has been demonstrated in other industries including manufacturing $[41,53$, 69], pharmaceutical $[25,38]$, food processing [70], animal feed, and biotechnology [43]. Like in baking environments, workers handling or in direct contact with fungal enzymes and with a history of atopy are at increased risk of becoming sensitized [10, 23, 24, 42, 52-56]. Sensitization to proteolytic enzymes has also been demonstrated in the manufacture of detergents $[53,71]$. In the future, additional uses for fungal enzymes in industrial environments will be identified. Recent examples include the use of $\alpha$-amylase and glucoamylase for the production of ethanol in the biofuel industry [72, 73]. If proper methods of exposure prevention are not followed and exposure is not monitored in these industries, it is possible that new groups of workers will suffer adverse health outcomes and become sensitized to enzymes. In the following sections we describe the major fungal enzymes, prevalence of sensitization, and occupational environment that they are most likely to be encountered.

\section{Fungal Enzyme Allergens}

3.1. $\alpha$-Amylase. Fungal amylase is the most well-characterized fungal enzyme used in the occupational environment.
Originally discovered by Takamine in 1884 [49], bakers have used $\alpha$-amylase as a supplement to cereal flour to improve carbohydrate fermentation by yeasts and ultimately the quality of the bread [49]. $\alpha$-amylase cleaves long-chain carbohydrates into simpler sugars including maltose [49]. Derived from $A$. oryzae, $\alpha$-amylase is a 478 amino acid glycoprotein with a molecular weight of $53 \mathrm{kDa}$ (Table 2; [6]). Occupational sensitization to $\alpha$-amylase was first reported by Flindt [61] and has subsequently been identified as an allergen in baking [74], pharmaceutical [25], animal feed [12], and biotechnology industries [43]. The allergen was originally designated Asp o 2 by the International Union of Immunological Societies (IUIS) Allergen Nomenclature Subcommittee but now has been redesignated Asp o 21 [27]. Since this preliminary work, $\alpha$-amylase has been identified as one of the principle sensitizers in large-scale bakeries [24, 56]. The prevalence of sensitization among bakers is variable and ranges from $0.9 \%$ to $34 \%[13,18,19,21,23,24,27-$ $35,54,66,67,75]$. Concentrations as high as $40 \mathrm{ng} \mathrm{m}^{-3}$ have been reported in baking environments [60]; however, $\alpha$-amylase concentrations in the low $\mathrm{ng} \mathrm{m}^{-3}$ range have been associated with an increased frequency of sensitization [58].

The most common tasks associated with $\alpha$-amylase exposure involve dispensing, sieving, weighing and mixing $[55,56,60]$. Exposures that exceed the maximum exposure limit for flour dust in the United Kingdom were identified in mixing, weighing [54], and dispensing operations [55]. The prevalence of sensitization to $\alpha$-amylase is 9.9 times greater among workers in high-exposure categories compared to those workers in low-exposure categories [55]. Aerosolized particle size distribution analysis in baking environments demonstrated that workers are exposed to $\alpha$ amylase particles within the inhalable size fraction [60]. OA is commonly identified in workers sensitized to $\alpha$-amylase. After bronchial provocation with $\alpha$-amylase, between 16 and $100 \%$ of sensitized workers were found to give a positive immediate response depending on the study [25, $35,49]$. Nasal provocation with $\alpha$-amylase in skin prick test (SPT) positive workers also induced rhinitis [26]. Furthermore, positive associations between $\alpha$-amylase SPT and work-related respiratory symptoms have been identified [23]. Interestingly, heating $\alpha$-amylase has been shown to reduce enzymatic and allergenic activity of the enzyme [76]. Potential sensitization of bakers' family members due to $\alpha$ amylase associated with clothes, shoes, and bakery textiles has also been reported by Vissers [77].

3.2. $\gamma$-Amylase $\gamma$-amylase or glucoamylase is primarily obtained from A. niger, A. awamori, and R. delemar. Glucoamylase is used as a dough additive by bakers, often in association with $\alpha$-amylase. The enzyme is also used in the production of high-glucose syrups [46]. Glucoamylase has a molecular weight of $68 \mathrm{kDa}$ (Table 2) and can remain functionally active at elevated $\mathrm{pH}$. Glucoamylase exposure has been primarily reported in baking occupations [10, 13, 18]; however, occupational exposure has also been reported in fruit and salad processing [52]. Sen et al. [52] demonstrated that three workers with shortness of breath, chest tightness, and wheeze had specific IgE to glucoamylase. Quirce et al. 
[18] also demonstrated positive SPT to glucoamylase in all tested subjects $(n=4)$; however, only three of the four patients elicited an early asthmatic response following bronchial provocation. Airborne glucoamylase was shown in $9 \%$ of air samples from a bakery [59], and median levels were $10.3 \mathrm{ng} \mathrm{m}^{-3}$. Moderate allergenic cross-reactivity has also been reported between glucoamylase and $\alpha$-amylase [18] .

3.3. Cellulase, Xylanase, and Hemicellulase. Cellulases are enzymes that hydrolize cellulose into glucose and are primarily used in the pharmaceutical, baking, detergent, and textile industries $[6,78]$. Cellulase has been purified from several rhizosphere fungi including A. niger and Trichoderma viride [49], as well as Humicola insolens [41]. The molecular weight of cellulases ranges from 22 to $45 \mathrm{kDa}$ (Table 2). Cellulases derived from these fungi are used in baking to break up roughage in dough and as a digestive aid in the food industry $[13,79,80]$. The first case of OA caused by cellulase was reported in 1981 in a plant pathologist $[49,81]$, and later these findings were confirmed in two pharmaceutical workers [80], four laboratory workers [14], and two bakers [49]. In each of these studies, the workers had specific IgE to the cellulase antigens. In 171 German bakers, the prevalence of sensitization to cellulase was $13 \%$ [13]. Airborne concentrations of cellulase have been quantified using a modified dot blot technique and were $<180 \mathrm{ng} \mathrm{m}^{-3}$ in a flour mill, crisp bread factory, and a bakery [82]. OA has also been reported to cellulase in the baking industry [83] as well as from $H$. insolens used in the detergent industry [41].

Endo 1, 4-beta-D-xylanase and beta-xylosidase are major enzymes involved in xylan hydrolysis [13]. Collectively termed xylanases, these enzymes are a type of hemicellulase that breaks down hemicelluloses, a major component in plant cell walls [13]. Besides $\alpha$-amylase, xylanases are the next most frequently used enzymes in the baking industry to remove pentosans from bread and increase bread volume $[13,49]$. The prevalence of IgE sensitization to hemicellulase was reported to be $8 \%$ [19] and $11 \%$ for xylanase [13]. Sander and colleagues [13] found that 7 of 8 bakers had serum IgE to a $105 \mathrm{kDa}$ protein in a xylanase ingredient. This protein was identified using mass spectrometry to be betaxylosidase derived from $A$. niger. The allergen was designated Asp $n 14$ by the IUIS Allergen Nomenclature Subcommittee (Table 2). Airborne concentrations of xylanase have been reported to be $<40 \mathrm{ng} \mathrm{m}^{-3}$ in a flourmill and crisp bread factory [82]. Concentrations as high as $200 \mathrm{ng} \mathrm{m}^{-3}$ were also reported in a bakery, but these values were associated with the natural xylanase activity of wheat [82]. Case reports have verified xylanase sensitization and the presence of an $\mathrm{IgE}$ mechanism in respiratory disease $[15,79]$. OA has also been reported to xylanase in the baking industry [83], and in a case report, a baker had an immediate asthmatic response following inhalation challenge [15]. Crossreactivity between cellulase and xylanase has been reported to be in the range of $80-90 \%$ but no cross-reactivity has been shown with $\alpha$-amylase [13, 14]. Similarly, workers can also be monosensitized to cellulase and xylanase without concomitant sensitization to $\alpha$-amylase [83].
3.4. Lactase. A. oryzae lactase is a high-molecular-weight protein that is involved in the hydrolysis of the disaccharide, lactose. Lactase is used in the pharmaceutical industry to develop dietary aids for patients intolerant to lactose. In a cross-sectional study of United States pharmaceutical workers, Bernstein and colleagues [38] identified 29\% of lactaseexposed workers to have positive SPT response to lactase. Workers with a positive SPT were nine times more likely to have respiratory symptoms than workers with a negative SPT [38]. Interestingly, atopy was not associated with the development of respiratory symptoms. Occupational sensitization to lactase has been reported in workers formulating and packaging gastrointestinal consumer products [39]. In inhalational challenge studies conducted by Laukkanin and colleagues [40], lactase was identified to induce occupational IgE-mediated respiratory sensitization. Interestingly, lactase exposure has also been identified to cause contact skin reactions [40].

3.5. Lipase. Lipase is an essential catalyst that digests waterinsoluble lipids. A. oryzae and $R$. oryzae lipase are used because of low extraction costs, thermal and $\mathrm{pH}$ stability, substrate specificity, and activity in organic solvents. Lipase is predominantly used in the manufacture of laundry detergents and in baking; however, other newer applications have been developed. For example, Candida antarctica lipase has recently been used as a biocatalyst for the biofuel industry [84]. The incidence of occupational sensitization to lipase, in industrial settings is understudied. In a preliminary analysis of detergent manufacturing workers, 3 workers were found to be sensitized to lipase and bronchial provocation tests provoked a reproducible asthmatic response [41]. A recent case study of a pharmaceutical manufacturing worker also demonstrated sensitization to fungal lipase derived from $R$. oryzae but not $A$. oryzae $\alpha$-amylase [44].

3.6. Phytase. A. niger and R. oligosporus produce phosphatase that catalyzes the hydrolysis of phytate to lower-order phosphate esters [16]. Termed phytase, this enzyme enhances phosphate bioavailability in the digestive tract and has been utilized in the animal feed industry during the last two decades [17]. Phytase accounts for $0.1-1 \%$ of total extractable protein from A. niger [17]. 3-phytase B derived from $A$. niger is an $84 \mathrm{kDa}$ protein that has been designated Asp n 25 by the IUIS Allergen Nomenclature Subcommittee (Table 2). Allergic sensitization to phytase has been reported in animal feed factory workers (7-90\%), and sensitization is highest at sites where phytase is handled in powdered form $[16,17,69,85]$. In a cross-sectional study of 53 technical center workers that produced A. niger phytase, $52 \%$ of workers in the high-exposure group and only $10 \%$ in the low-exposure group were sensitized to phytase [16]. Personal exposure to phytase has been shown to exacerbate OA, and inhalation challenge tests produced immediate asthmatic response [86]. It has been proposed that phytase is highly sensitizing and that direct contact should be avoided in this industry [16]. 
3.7. Enzymes Used in Health Care Settings: Biodiastase and Flaviastase. Fungal enzymes have a number of applications in the healthcare environment. Fungal enzymes derived from $A$. niger are used in powdered form with other enzyme extracts by pharmacists to prepare digestive powders. Biodiastase and Flaviastase are two examples of fungal enzymes that have been associated with sensitization in hospital workers and pharmaceutical workers handling these products $[10,12-21,23-35,38-44,51-88]$. To date, health effects in workers exposed to these enzymes remain poorly characterized.

3.8. EPg22 Protease: Aspartic Protease. The aspartic proteases produced by Rhizomucor miehei and Cryphonectria parasitica are utilized in almost half of the cheese production operations throughout the world [46]. The proteases assist in milk clotting and facilitate a change in cheese properties by hydrolyzing certain peptide bonds. Occupational exposure to these proteases has been associated with occupational sensitization in a rennet production plant [11]. Specifically $29 \%$ and $6 \%$ of workers had a positive skin prick test (SPT) to $R$. miehei and C. parasitica aspartic protease extracts, respectively [11]. Other novel enzymes with potential application in the food processing industry have been identified. Pg222 is a novel extracellular protease produced by $P$. chrysogenum (Pg222). The enzyme was isolated from dry-cured hams and was found to have a broad range of applications in industries that produce dry-cured meat products [89]. Although no occupational sensitization has been reported to this enzyme, it demonstrates that the introduction of any new enzyme could potentially represent an occupational hazard.

\section{Emerging Occupational Fungal Enzyme Exposures}

The utility of fungal enzymes to degrade xenobiotics and organic compounds in the industrial sector continues to be recognized [46]. Fungal enzymes are now being used for a variety of purposes across many different industries. Improved biochemical and molecular technologies have enabled the production of other potentially allergenic proteins [14]. According to Baur [10], more than 186 commercial enzymes were produced in the European Union in 2001, and many of these were produced by recombinant technology or had been genetically engineered. Table 1 provides a summary of the major fungal enzymes that are utilized in industrial settings. All of the aforementioned enzymes that are listed in Table 1 have been identified to be potent allergens in the workplace; however, the ability of the other listed enzymes to cause adverse health outcomes following occupational exposure remains unclear.

Several of the enzymes presented in Table 1, not identified as occupational allergens, have been identified as allergens associated with environmental bioaerosols. Catalase, a fungal enzyme utilized in hygiene products, pharmaceuticals, and textiles, has been identified as an allergen in the entomopathogenic fungus, Metarhizium anisopliae [90]. Pectinase is used in brewing and wine production, food processing, and paper industries and allergy to pectinase has been associated with occupational exposure [91]. Esterase has been identified as an allergen in Hevea brasiliensis (natural rubber latex) [92]. Beta-glucanase is used to improve the nutritional yield of animal feeds, and occupational exposure has been shown in a case study to significantly reduce forced vital capacity and forced expired volume in 1 second (FEV1) [86]. The worker in this case study was also SPT positive and had specific IgE to beta-glucanase [86]. In the biotechnology and pharmaceutical industries, glutathione-Stransferase (GST) has a number of applications. GST is an approximately $26 \mathrm{kDa}$ protein that has been identified as a major Alternaria alternata allergen and is highly conserved across fungi $[45,93,94]$. The IUIS Allergen Nomenclature Subcommittee has designated this allergen Alt a 13 [93, 94]. Interestingly, alpha-galactosidase has been associated with delayed anaphylaxis, angioedema, or urticaria in sensitized patients following the ingestion of beef, pork, or lamb [95]. Although the role of alpha-galactosidase and these other enzymes following occupational exposure remains unclear, these studies provide preliminary insight into the possible potency of these allergens in industrial environments.

\section{Immunodiagnostic Detection Methodologies}

Occupational allergic sensitization to fungal enzymes is diagnosed clinically using available in vivo SPT reagents, or in vitro assays such as Phadia ImmunoCap [7]. However, SPT reagents for most of the fungal enzymes used in industrial settings are not commercially available and have to be either custom ordered or prepared individually by the investigator. Methods for SPT extract preparation that are used by investigators in the field have been previously described by Quirce et al. [49]. In vitro diagnostic tools that can quantify the amount of specific IgE to an occupational allergen are not readily available except in research laboratories where investigators prepare their own inhibition or radioallergosorbent enzyme-linked immunosorbent assay (ELISA) to quantify specific $\operatorname{IgE}[36,49]$. To date, $\alpha$-amylase $(\mathrm{k} 87)$ is the only fungal enzyme available on the Phadia ImmunoCap testing panel. To confirm OA caused by fungal enzymes, bronchial provocation tests can be undertaken to document immediate or late-phase responses to fungal enzymes [36, 49]. Positive immediate response criteria used in workers exposed to enzymes include a greater than $20 \%$ fall in FEV1, whereas a late-phase response has been considered positive when there is a $30 \%$ or greater fall in peak expiratory flow rate [49]. However, there are several limitations with bronchial provocation tests that should be considered; these are discussed in detail by Peden and Reed [7].

In order to better understand the relationships between occupational fungal enzyme exposure and clinical symptomology, accurate information on the distribution and quantity of the fungal enzyme in the occupational environment will be required. Immunodiagnostic methods that utilize antibodies could provide standardized methods for quantifying fungal enzyme biomarkers in a variety of 
occupational environments. Following validation and interlaboratory comparison, the assays could be used for exposure assessment to determine the existence of exposure-response relationships $[58,96]$. This information is critical for the development of future threshold limit values (TLVs) and other occupational standards.

Several antibodies and immunodiagnostic methods have been produced to detect industrial fungal enzymes, in particular $\alpha$-amylase. These methods have been employed in field investigations and used to quantify the concentration of the enzyme from collected air samples. Bogdanovic et al. [97] used an enzyme immunoassay with a sensitivity of $25 \mathrm{pg} / \mathrm{mL}$ to quantify $\alpha$-amylase in airborne and surface dust samples collected from five bakeries. In the same study, a lateral flow immunoassay for $\alpha$-amylase was compared to the reference enzyme immunoassay. The sensitivity of the lateral flow assay was $1-10 \mathrm{ng} / \mathrm{mL}$, and extracts with $>5 \mathrm{ng} / \mathrm{mL}$ allergen were positive in the lateral flow assay [97]. In a study of 507 personal air samples, Houba and colleagues [60] used a rabbit IgG capture immunoassay to quantify $\alpha$-amylase in specific baking job category. Concentrations of $\alpha$-amylase up to $40 \mathrm{ng} \mathrm{m}^{-3}$ were quantified, and workers directly involved with dough preparation had the highest exposures [60]. Using the same rabbit IgG sandwich assay, Nieuwenhuijsen et al. [55] identified dispensing and mixing areas to have the highest $\alpha$-amylase exposure in British bakeries and flour mills. Two monoclonal antibody- (mAb-) based ELISAs have been developed for the detection of $\alpha$-amylase in the occupational environment. Assay sensitivities ranged from $0.2 \mathrm{ng} / \mathrm{mL}$ [98] to $0.6 \mathrm{ng} / \mathrm{mL}$ [99]. A quantitative mAbmediated dot blot assay has also been previously described for cellulase and xylase; the detection limits reported were $20 \mathrm{ng} \mathrm{m}^{-3}$ and $2 \mathrm{ng} \mathrm{m}^{-3}$, respectively [82]. mAbs to other fungal enzymes, such as xylanase have been produced and reported in the literature [100]. Similarly, the detergent industry has produced antibodies and immunoassays for several common fungal enzymes and these have been utilized in industrial hygiene safety programs to mitigate worker exposures [101-103]. Unfortunately, for many other fungal enzymes presented in Table 1, there are no commercially available antibodies to enable quantification in the occupational environment. The development of fungal enzymespecific mAbs in combination with immunodiagnostic techniques will further our knowledge of the exposure-response relationships in occupational environments. Using these methods will also help enable the development of standards and focus on the prevention of sensitization in heavily contaminated work environments.

\section{Allergen Avoidance and Directions for the Future}

Exposure to fungal enzymes, in particular $\alpha$-amylase, is a considerable health risk in a number of industries. Crosssectional studies have shown that processing workers in high-exposure categories who handled fungal enzymes are up to ten times more likely to be sensitized to fungal enzymes than workers in the low-exposure category [55].
Highest concentrations of enzymes in the inhalable fraction were encountered among workers located in dispensing, mixing, weighing, and sieving occupations $[54-56,60]$. Airborne concentrations as high as $40 \mathrm{ng} \mathrm{m}^{-3}$ and in some cases even higher $\left(200 \mathrm{ng} \mathrm{m}^{-3}\right)$ have been reported for sensitized workers located in these handling areas $[12,55$, 60]. Concentrations in the low $\mathrm{ng} \mathrm{m}^{-3}$ range have been associated with an increased frequency of sensitization [58]. For other fungal enzymes, such as phytase, similar findings have been reported [16].

The continued utilization of other previously overlooked enzymes as well as new genetically engineered enzymes in various industries will continue to provide diagnostic challenges, even for the most seasoned occupational medicine professional. It is likely that new cases of occupational allergic disease will emerge following exposure to fungal industrial enzymes during the next decade. In response, identification of exposure-response relationships will be critical for the development of TLVs and occupational exposure levels. However, this will depend on the development of suitable diagnostic antibodies and immunoassays. Currently, subtilisin, a sereine endopeptidase derived from Bacillus subtilis, is the only enzyme for which the American Conference of Governmental Industrial Hygienists (ACGIH) has established a TLV value $\left(60 \mathrm{ng} \mathrm{m}^{-3}\right)$. The European Union Directive also classifies the fungal enzymes cellulase and $\alpha$-amylase with the risk phrase R42 (may cause sensitization by inhalation) [10]. There are currently no consensus standards for other industrially utilized fungal enzymes.

As a precautionary measure, it has been concluded that all enzymes should be regarded as an allergen that can exacerbate respiratory sensitization in susceptible populations $[10,59]$. Baur [10] has further proposed that all enzymes should be classified as R42 according to the European Union Directive criteria. Although intervention in the bakery industry has had little to no effect [104], installation of engineering controls and implementation of personal protective equipment programs in animal feed workers exposed to phytase was shown to result in the immediate cessation of hypersensitivity symptoms [10]. Improvements in biotechnology have also included the encapsulation of some enzymes [105, 106] and proteins [107]. These engineering controls have been proposed to reduce occupational exposure to enzymes; however, encapsulation alone may not completely prevent enzyme-induced allergy and OA $[108,109]$. To date, the detergent industry has implemented a derived minimal effect level (DMEL) of $60 \mathrm{ng} \mathrm{m}^{-3}$ for pure enzyme proteins [110]. Although this DMEL was provided as guidance by the ACGIH, other manufacturers have implemented their own occupational exposure guidelines (OEGs) for fungal enzymes such as $\alpha$-amylase $\left(5-15 \mathrm{ng} \mathrm{m}^{-3}\right)$, lipase $\left(5-20 \mathrm{ng} \mathrm{m}^{-3}\right)$, and cellulase $\left(8-20 \mathrm{ng} \mathrm{m}^{-3}\right)$ [110]. In addition, the detergent industry has developed a medical surveillance program to identify and correct elevated exposures before occupational illnesses occur [101-103, 111]. As a result, the incidence of occupational allergy has dropped substantially [101-103]. Implementation of DMELs and OEGs will further assist in the reduction of occupational exposure. Reducing worker exposure to fungal enzymes in industry by the implementation 
of engineering controls and other allergen avoidance strategies will continue to mitigate personal exposure and further reduce the occupational health risk.

\section{Acknowledgments}

This work was supported in part by an interagency agreement with NIEHS (Y1-ES-0001). The findings and conclusions in this paper are those of the authors and do not necessarily represent the views of the National Institute for Occupational Safety and Health.

\section{References}

[1] U. S. Department of Labor, "Employment status of the civilian noninstitutional population, 1940 to date," Bureau of Labor Statistics, Washington, DC, USA, 2010, 2010, http://www.bls.gov/cps/cpsaat1.pdf.

[2] February 2011, http://www.healthypeople.gov/2020/topicsobjectives2020/overview.aspx?topicid $=30$.

[3] B. T. Butcher and J. E. Salvaggio, "Occupational asthma," Journal of Allergy and Clinical Immunology, vol. 78, no. 4 I, pp. 547-556, 1986.

[4] J. Dutkiewicz, L. Jablonski, and S. A. Olenchock, "Occupational biohazards: a review," American Journal of Industrial Medicine, vol. 14, no. 5, pp. 605-623, 1988.

[5] J. Lacey and B. Crook, "Fungal and actinomycete spores as pollutants of the workplace and occupational allergens," Annals of Occupational Hygiene, vol. 32, no. 4, pp. 515-533, 1988.

[6] F. Lachowsky and M. Lopez, "Occupational allergens," Current Allergy and Asthma Reports, vol. 1, no. 6, pp. 587-593, 2001.

[7] D. Peden and C. E. Reed, "Environmental and occupational allergies," Journal of Allergy and Clinical Immunology, vol. 125, no. 2, pp. S150-S160, 2010.

[8] E. L. Petsonk, "Work-related asthma and implications for the general public," Environmental Health Perspectives, vol. 110, suuplement 4, pp. 569-572, 2002.

[9] C. E. Mapp, "Genetics and the occupational environment," Current Opinion in Allergy and Clinical Immunology, vol. 5, no. 2, pp. 113-118, 2005.

[10] X. Baur, "Enzymes as occupational and environmental respiratory sensitisers," International Archives of Occupational and Environmental Health, vol. 78, no. 4, pp. 279-286, 2005.

[11] A. Jensen, S. Dahl, D. Sherson, and B. Sommer, "Respiratory complaints and high sensitization rate at a rennet-producing plant," American Journal of Industrial Medicine, vol. 49, no. 10, pp. 858-861, 2006.

[12] M. Vanhanen, T. Tuomi, U. Tiikkainen et al., "Sensitisation to enzymes in the animal feed industry," Occupational and Environmental Medicine, vol. 58, no. 2, pp. 119-123, 2001.

[13] I. Sander, M. Raulf-Heimsoth, C. Siethoff, C. Lohaus, H. E. Meyer, and X. Baur, "Allergy to Aspergillus-derived enzymes in the baking industry: identification of $\beta$-xylosidase from Aspergillus niger as a new allergen (Asp n 14)," Journal of Allergy and Clinical Immunology, vol. 102, no. 2, pp. 256-264, 1998.

[14] K. Tarvainen, L. Kanerva, O. Tupasela et al., "Allergy from cellulase and xylanase enzymes," Clinical and Experimental Allergy, vol. 21, no. 5, pp. 609-615, 1991.

[15] X. Baur, I. Sander, A. Posch, and M. Raulf-Heimsoth, "Baker's asthma due to the enzyme xylanase-a new occupational allergen," Clinical and Experimental Allergy, vol. 28, no. 12, pp. 1591-1593, 1998.
[16] X. Baur, S. Melching-Kollmuss, F. Koops, K. Straßburger, and A. Zober, "IgE-mediated allergy to phytase-a new animal feed additive," Allergy, vol. 57, no. 10, pp. 943-945, 2002.

[17] G. Doekes, N. Kamminga, L. Helwegen, and D. Heederik, "Occupational IgE sensitisation to phytase, a phosphatase derived from Aspergillus niger," Occupational and Environmental Medicine, vol. 56, no. 7, pp. 454-459, 1999.

[18] S. Quirce, M. Fernández-Nieto, B. Bartolomé, C. Bombín, M. Cuevas, and J. Sastre, "Glucoamylase: another fungal enzyme associated with baker's asthma," Annals of Allergy, Asthma and Immunology, vol. 89, no. 2, pp. 197-202, 2002.

[19] X. Baur, W. Sauer, and W. Weiss, "Baking additives as new allergens in Baker's asthma," Respiration, vol. 54, no. 1, pp. 70-72, 1988.

[20] S. Quirce, M. Fernández-Nieto, C. Escudero, J. Cuesta, M. De Las Heras, and J. Sastre, "Bronchial responsiveness to bakery-derived allergens is strongly dependent on specific skin sensitivity," Allergy, vol. 61, no. 10, pp. 1202-1208, 2006.

[21] J. Elms, D. Fishwick, J. Walker et al., "Prevalence of sensitisation to cellulase and xylanase in bakery workers," Occupational and Environmental Medicine, vol. 60, no. 10, pp. 802-804, 2003.

[22] R. E. Biagini, B. A. MacKenzie, D. L. Sammons et al., "Evaluation of the prevalence of antiwheat-, anti-flour dust, and anti- $\alpha$-amylase specific IgE antibodies in US blood donors," Annals of Allergy, Asthma and Immunology, vol. 92, no. 6, pp. 649-653, 2004.

[23] R. Houba, D. J. J. Heederik, G. Doekes, and P. E. M. van Run, "Exposure-sensitization relationship for $\alpha$-amylase allergens in the baking industry," American Journal of Respiratory and Critical Care Medicine, vol. 154, no. 1, pp. 130-136, 1996.

[24] T. A. Smith and P. W. Smith, "Respiratory symptoms and sensitization in bread and cake bakers," Occupational Medicine, vol. 48, no. 5, pp. 321-328, 1998.

[25] E. Losada, M. Hinojosa, S. Quirce, M. Sánchez-Cano, and I. Moneo, "Occupational asthma caused by $\alpha$-amylase inhalation: clinical and immunologic findings and bronchial response patterns," Journal of Allergy and Clinical Immunology, vol. 89, no. 1 I, pp. 118-125, 1992.

[26] J. Brisman and L. Belin, "Clinical and immunological responses to occupational exposure to $\alpha$-amylase in the baking industry," British Journal of Industrial Medicine, vol. 48, no. 9, pp. 604-608, 1991.

[27] X. Baur, Z. Chen, and I. Sander, "Isolation and denomination of an important allergen in baking additives: $\alpha$-amylase from Aspergillus oryzae (Asp o II)," Clinical and Experimental Allergy, vol. 24, no. 5, pp. 465-470, 1994.

[28] J. Brisman, L. Lillienberg, L. Belin, M. Åhman, and B. Järvholm, "Sensitisation to occupational allergens in bakers' asthma and rhinitis: a case-referent study," International Archives of Occupational and Environmental Health, vol. 76, no. 2, pp. 167-170, 2003.

[29] T. A. Smith, G. Parker, and T. Hussain, "Respiratory symptoms and wheat flour exposure: a study of flour millers," Occupational Medicine, vol. 50, no. 1, pp. 25-29, 2000.

[30] X. Baur, P. O. Degens, and I. Sander, "Baker's asthma: still among the most frequent occupational respiratory disorders," Journal of Allergy and Clinical Immunology, vol. 102, no. 6, pp. 984-997, 1998.

[31] A. Brant, J. Berriman, C. Sharp et al., "The changing distribution of occupational asthma: a survey of supermarket bakery workers," European Respiratory Journal, vol. 25, no. 2, pp. 303-308, 2005.

[32] T. A. Smith, K. P. S. Lumley, and E. H. K. Hui, "Allergy to flour and fungal amylase in bakery workers," Occupational Medicine, vol. 47, no. 1, pp. 21-24, 1997. 
[33] J. Walusiak, W. Hanke, P. Górski, and C. Pałczyński, "Respiratory allergy in apprentice bakers: do occupational allergies follow the allergic march?" Allergy, vol. 59, no. 4, pp. 442 450, 2004.

[34] A. Bataille, M. Anton, F. Mollat et al., "Respiratory allergies among symptomatic bakers and pastry cooks: initial results of a prevalence study," Allergy and Immunology, vol. 27, pp. 7-10, 1995.

[35] J. Birnbaum, F. Latil, D. Vervloet, M. Senft, and J. Charpin, "The role of alpha-amylase in baker's asthma," Revue des Maladies Respiratoires, vol. 5, no. 5, pp. 519-521, 1988.

[36] W. E. Horner, M. Armstrong, J. El-Dahr et al., "Prevalence of IgE reactivities in mold-allergic subjects to commercially available fungal enzymes," Allergy and Asthma Proceedings, vol. 29, no. 6, pp. 629-635, 2008.

[37] T. Storaas, S. K. Steinsvåg, E. Florvaag, A. Irgens, and T. B. Aasen, "Occupational rhinitis: diagnostic criteria, relation to lower airway symptoms and IgE sensitization in bakery workers," Acta Oto-Laryngologica, vol. 125, no. 11, pp. 12111217, 2005.

[38] J. A. Bernstein, D. I. Bernstein, T. Stauder, Z. Lummus, and I. L. Bernstein, "A cross-sectional survey of sensitization to Aspergillus oryzae-derived lactase in pharmaceutical workers," Journal of Allergy and Clinical Immunology, vol. 103, no. 6, pp. 1153-1157, 1999.

[39] D. C. F. Muir, A. B. Verrall, J. A. Julian, J. M. Millman, M. A. Beaudin, and J. Dolovich, "Occupational sensitization to lactase," American Journal of Industrial Medicine, vol. 31, no. 5, pp. 570-571, 1997.

[40] A. Laukkanen, P. Ruoppi, S. Remes, T. Koistinen, and S. Mäkinen-Kiljunen, "Lactase-induced occupational protein contact dermatitis and allergic rhinoconjunctivitis," Contact Dermatitis, vol. 57, no. 2, pp. 89-93, 2007.

[41] A. Brant, A. Hole, J. Cannon et al., "Occupational asthma caused by cellulase and lipase in the detergent industry," Occupational and Environmental Medicine, vol. 61, no. 9, pp. 793-795, 2004.

[42] C. R. Johnsen, T. B. Sorensen, A. I. Larsen et al., "Allergy risk in an enzyme producing plant: a retrospective follow up study," Occupational and Environmental Medicine, vol. 54, no. 9, pp. 671-675, 1997.

[43] M. Vanhanen, T. Tuomi, H. Nordman et al., "Sensitization to industrial enzymes in enzyme research and production," Scandinavian Journal of Work, Environment and Health, vol. 23, no. 5, pp. 385-391, 1997.

[44] G. Loureiro, B. Tavares, C. Pereira, M. Lundberg, and C. Chieira, "Occupational allergy to fungal lipase in the pharmaceutical industry," Journal of Investigational Allergology and Clinical Immunology, vol. 19, no. 3, pp. 242-244, 2009.

[45] B. Simon-Nobbe, U. Denk, V. Pöll, R. Rid, and M. Breitenbach, "The spectrum of fungal allergy," International Archives of Allergy and Immunology, vol. 145, no. 1, pp. 58-86, 2008.

[46] N. A. Gow and G. M. Gadd, The Growing Fungus, Chapman and Hall, London, UK, 1995.

[47] K. Ban, M. Kaieda, T. Matsumoto, A. Kondo, and H. Fukuda, "Whole cell biocatalyst for biodiesel fuel production utilizing Rhizopus oryzae cells immobilized within biomass support particles," Biochemical Engineering Journal, vol. 8, no. 1, pp. 39-43, 2001.

[48] P. Fickers, P. H. Benetti, Y. Waché et al., "Hydrophobic substrate utilisation by the yeast Yarrowia lipolytica, and its potential applications," Federation of European Microbiological Societies Yeast Research, vol. 5, no. 6-7, pp. 527-543, 2005.

[49] S. Quirce, M. Cuevas, M. L. Diez-Gomez et al., "Respiratory allergy to Aspergillus-derived enzymes in bakers' asthma,"
Journal of Allergy and Clinical Immunology, vol. 90, no. 6 I, pp. 970-978, 1992.

[50] P. Baldrian, "Fungal laccases-occurrence and properties," Federation of European Microbiological Societies Microbiology Reviews, vol. 30, no. 2, pp. 215-242, 2006.

[51] W. E. Horner, G. Reese, and S. B. Lehrer, "Identification of the allergen Psi c 2 from the basidiomycete Psilocybe cubensis as a fungal cyclophilin," International Archives of Allergy and Immunology, vol. 107, no. 1-3, pp. 298-300, 1995.

[52] D. Sen, K. Wiley, and J. G. Williams, "Occupational asthma in fruit salad processing," Clinical and Experimental Allergy, vol. 28, no. 3, pp. 363-367, 1998.

[53] F. G. B. G. J. van Rooy, R. Houba, N. Palmen et al., "A cross-sectional study among detergent workers exposed to liquid detergent enzymes," Occupational and Environmental Medicine, vol. 66, no. 11, pp. 759-765, 2009.

[54] J. Elms, P. Beckett, P. Griffin et al., "Job categories and their effect on exposure to fungal alpha-amylase and inhalable dust in the U.K. baking industry," American Industrial Hygiene Association Journal, vol. 64, no. 4, pp. 467-471, 2003.

[55] M. J. Nieuwenhuijsen, D. Heederik, G. Doekes, K. M. Venables, and A. J. Newman Taylor, "Exposure-response relations of $\alpha$-amylase sensitisation in British bakeries and flour mills," Occupational and Environmental Medicine, vol. 56, no. 3, pp. 197-201, 1999.

[56] T. A. Smith and K. P. S. Lumley, "Work-related asthma in a population exposed to grain, flour and other ingredient dusts," Occupational Medicine, vol. 46, no. 1, pp. 37-40, 1996.

[57] I. Sander, C. Neuhaus-Schröder, M. Raulf-Heimsoth, C. Doekes, D. Heederik, and X. Baur, "Quantification of the inhalable exposure to $\alpha$-amylase in two bakeries," Pneumologie, vol. 52, no. 8, pp. 440-443, 1998.

[58] D. Heederik, "Are we closer to developing threshold limit values for allergens in the workplace?" Current Opinion in Allergy and Clinical Immunology, vol. 1, no. 2, pp. 185-189, 2001.

[59] J. Elms, E. Robinson, H. Mason, S. Iqbal, A. Garrod, and G. S. Evans, "Enzyme exposure in the British baking industry," Annals of Occupational Hygiene, vol. 50, no. 4, pp. 379-384, 2006.

[60] R. Houba, P. van Run, G. Doekes, D. Heederik, and J. Spithoven, "Airborne levels of $\alpha$-amylase allergens in bakeries," Journal of Allergy and Clinical Immunology, vol. 99, no. 3, pp. 286-292, 1997.

[61] M. L. H. Flindt, "Allergy to $\alpha$-amylase and papain," The Lancet, vol. 1, no. 8131, pp. 1407-1408, 1979.

[62] X. Baur, G. Fruhmann, B. Haug, B. Rasche, W. Reiher, and W. Weiss, "Role of Aspergillus amylase in baker's asthma," The Lancet, vol. 1, no. 8471, p. 43, 1986.

[63] T. Skjold, R. Dahl, B. Juhl, and T. Sigsgaard, "The incidence of respiratory symptoms and sensitisation in baker apprentices," European Respiratory Journal, vol. 32, no. 2, pp. 452459, 2008.

[64] V. C. Moore, P. Cullinan, S. Sadhra, and P. S. Burge, "Peak expiratory flow analysis in workers exposed to detergent enzymes," Occupational Medicine, vol. 59, no. 6, pp. 418-423, 2009.

[65] T. Skjold, S. C. Nielsen, K. Adolf, H. J. Hoffmann, R. Dahl, and T. Sigsgaard, "Allergy in bakers' apprentices and factors associated to non-participation in a cohort study of allergic sensitization," International Archives of Occupational and Environmental Health, vol. 80, no. 5, pp. 458-464, 2007.

[66] P. Cullinan, A. Cook, M. Jones, J. Cannon, B. Fitzgerald, and A. J. Newman Taylor, "Clinical responses to ingested fungal $\alpha$-amylase and hemicellulase in persons sensitized to 
Aspergillus fumigatus?" Allergy, vol. 52, no. 3, pp. 346-349, 1997.

[67] R. Baatjies, A. L. Lopata, I. Sander et al., "Determinants of asthma phenotypes in supermarket bakery workers," European Respiratory Journal, vol. 34, no. 4, pp. 825-833, 2009.

[68] E. H. Page, C. H. Dowell, C. A. Mueller, R. E. Biagini, and D. Heederik, "Exposure to flour dust and sensitization among bakery employees," American Journal of Industrial Medicine, vol. 53, no. 12, pp. 1225-1232, 2010.

[69] V. van Kampen, R. Merget, and T. Brüning, "Occupational allergies to phytase," Pneumologie, vol. 62, no. 12, pp. 707$710,2008$.

[70] R. Casper, M. C. Zacharisen, and J. N. Fink, "Occupational asthma secondary to enzymes used in cheese production," Allergy and Asthma Proceedings, vol. 29, no. 4, pp. 376-379, 2008.

[71] O. Kizkin, G. Turker, S. S. Hacievliyagil, and H. Gunen, "Proteolytic enzyme sensitivity and decrease in respiratory function (a 10-year follow-up)," International Archives of Occupational and Environmental Health, vol. 75, no. 6, pp. 441-444, 2002.

[72] H. Shigechi, J. Koh, Y. Fujita et al., "Direct production of ethanol from raw corn starch via fermentation by use of a novel surface-engineered yeast strain codisplaying glucoamylase and $\alpha$-amylase," Applied and Environmental Microbiology, vol. 70, no. 8, pp. 5037-5040, 2004.

[73] D. M. Mousdale, Biofuels: Biotechnology, Chemistry, and Sustainable Development, CRC Press, Taylor and Francis Group, Boca Raton, Fla, USA, 2008.

[74] C. P. Sandiford, R. D. Tee, and A. J. Newman Taylor, "The role of cereal and fungal amylases in cereal flour hypersensitivity," Clinical and Experimental Allergy, vol. 24, no. 6, pp. 549-557, 1994.

[75] J. Brisman, "Baker's asthma," Occupational and Environmental Medicine, vol. 59, no. 7, pp. 498-502, 2002.

[76] X. Baur, A. B. Czuppon, and I. Sander, "Heating inactivates the enzymatic activity and partially inactivates the allergenic activity of Asp o 2," Clinical and Experimental Allergy, vol. 26, no. 2, pp. 232-234, 1996.

[77] M. Vissers, G. Doekes, and D. Heederik, "Exposure to wheat allergen and fungal $\alpha$-amylase in the homes of bakers," Clinical and Experimental Allergy, vol. 31, no. 10, pp. 15771582, 2001.

[78] H. Y. Kim, D. H. Nahm, H. S. Park, and D. C. Choi, "Occupational asthma and IgE sensitization to cellulase in a textile industry worker," Annals of Allergy, Asthma and Immunology, vol. 82, no. 2, pp. 174-178, 1999.

[79] V. van Kampen, R. Merget, and T. Brüning, "Occupational allergies to xylanases," Pneumologie, vol. 58, no. 2, pp. 103106, 2004.

[80] E. Losada, M. Hinojosa, and I. Moneo, "Occupational asthma caused by cellulase," Journal of Allergy and Clinical Immunology, vol. 77, no. 4, pp. 635-639, 1986.

[81] J. H. Ransom and M. Schuster, "Allergic reactions to enzymes used in plant cloning experiments," Journal of Allergy and Clinical Immunology, vol. 67, no. 5, pp. 412-415, 1981.

[82] M. Vanhanen, T. Tuomi, H. Hokkanen et al., "Enzyme exposure and enzyme sensitisation in the baking industry," Occupational and Environmental Medicine, vol. 53, no. 10, pp. 670-676, 1996.

[83] R. Merget, I. Sander, M. Raulf-Heimsoth, and X. Baur, "Baker's asthma due to xylanase and cellulase without sensitization to alpha-amylase and only weak sensitization to flour," International Archives of Allergy and Immunology, vol. 124, no. 4, pp. 502-505, 2001.

[84] Z. Guo and X. Xu, "New opportunity for enzymatic modification of fats and oils with industrial potentials," Organic and Biomolecular Chemistry, vol. 3, no. 14, pp. 2615-2619, 2005.

[85] M. L. Caballero, M. Gómez, M. González-Muñoz et al., "Occupational sensitization to fungal enzymes used in animal feed industry," International Archives of Allergy and Immunology, vol. 144, no. 3, pp. 231-239, 2007.

[86] T. M. O'Connor, J. F. Bourke, M. Jones, and N. Brennan, "Report of occupational asthma due to phytase and $\beta$ glucanase," Occupational and Environmental Medicine, vol. 58, no. 6, pp. 417-419, 2001.

[87] G. Y. Hur, S. Y. Shin, Y. M. Ye, D. H. Nahm, and H. S. Park, "Two cases of occupational rhinitis caused by biodiastase in hospital and pharmaceutical workers," Allergy, vol. 62, no. 9, pp. 1096-1097, 2007.

[88] R. Pauwels, M. Devos, L. Callens, and M. van der Straeten, "Respiratory hazards from proteolytic enzymes," The Lancet, vol. 1, no. 8065, p. 669, 1978.

[89] M. J. Benito, I. F. Connerton, and J. J. Córdoba, "Genetic characterization and expression of the novel fungal protease, EPg222 active in dry-cured meat products," Applied Microbiology and Biotechnology, vol. 73, no. 2, pp. 356-365, 2006.

[90] M. D. W. Ward, M. J. Donohue, Y. J. Chung et al., "Human serum IgE reacts with a Metarhizium anisopliae fungal catalase," International Archives of Allergy and Immunology, vol. 150, no. 4, pp. 343-351, 2009.

[91] L. Belleri, E. Brunelli, M. Crippa, M. Golia, O. Vanoni, and L. Alessio, "Occupational exposure to pectinase," Allergy, vol. 57 , no. 8, p. 755, 2002.

[92] P. Rougé, R. Culerrier, M. Campistron et al., "Allergenicity of Hev b 13, a major esterase allergen in natural rubber latex (Hevea brasiliensis) allergy, does not only depend on its carbohydrate moiety," Molecular Immunology, vol. 47, no. 4, pp. 871-877, 2010.

[93] J. Shankar, P. D. Gupta, S. Sridhara, B. P. Singh, S. N. Gaur, and N. Arora, "Immunobiochemical analysis of crossreactive glutathione-S-transferase allergen from different fungal sources," Immunological Investigations, vol. 34, no. 1, pp. 37-51, 2005.

[94] J. Shankar, B. P. Singh, S. N. Gaur, and N. Arora, "Recombinant glutathione-S-transferase a major allergen from Alternaria alternata for clinical use in allergy patients," Molecular Immunology, vol. 43, no. 12, pp. 1927-1932, 2006.

[95] S. P. Commins, S. M. Satinover, J. Hosen et al., "Delayed anaphylaxis, angioedema, or urticaria after consumption of red meat in patients with IgE antibodies specific for galactose- $\alpha$-1,3-galactose," Journal of Allergy and Clinical Immunology, vol. 123, no. 2, pp. 426-433, 2009.

[96] D. Heederik, G. Doekes, and M. J. Nieuwenhuijsen, "Exposure assessment of high molecular weight sensitisers: contribution to occupational epidemiology and disease prevention," Occupational and Environmental Medicine, vol. 56, no. 11, pp. 735-741, 1999.

[97] J. Bogdanovic, M. Koets, I. Sander et al., "Rapid detection of fungal $\alpha$-amylase in the work environment with a lateral flow immunoassay," Journal of Allergy and Clinical Immunology, vol. 118, no. 5, pp. 1157-1163, 2006.

[98] J. Elms, S. Denniss, M. Smith et al., "Development and validation of a monoclonal based immunoassay for the measurement of fungal alpha-amylase: focus on peak exposures," Annals of Occupational Hygiene, vol. 45, no. 2, pp. 89-95, 2001. 
[99] I. Sander, C. Neuhaus-Schröder, G. Borowitzki, X. Baur, and M. Raulf-Heimsoth, "Development of a two-site enzymelinked immunosorbent assay for $\gamma$-amylase from Aspergillus oryzae based on monoclonal antibodies," Journal of Immunological Methods, vol. 210, no. 1, pp. 93-101, 1997.

[100] W. Kurzatkowski, A. Törrönen, J. Filipek et al., "Glucoseinduced secretion of Trichoderma reesei xylanases," Applied and Environmental Microbiology, vol. 62, no. 8, pp. 28592865, 1996.

[101] K. Sarlo, "Control of occupational asthma and allergy in the detergent industry," Annals of Allergy, Asthma and Immunology, vol. 90, no. 5, pp. 32-34, 2003.

[102] K. Sarlo and D. B. Kirchner, "Occupational asthma and allergy in the detergent industry: new developments," Current Opinion in Allergy and Clinical Immunology, vol. 2, no. 2, pp. 97-101, 2002.

[103] M. K. Schweigert, D. P. Mackenzie, and K. Sarlo, "Occupational asthma and allergy associated with the use of enzymes in the detergent industry-a review of the epidemiology, toxicology and methods of prevention," Clinical and Experimental Allergy, vol. 30, no. 11, pp. 1511-1518, 2000.

[104] T. Meijster, E. Tielemans, and D. Heederik, "Effect of an intervention aimed at reducing the risk of allergic respiratory disease in bakers: change in flour dust and fungal alphaamylase levels," Occupational and Environmental Medicine, vol. 66, no. 8, pp. 543-549, 2009.

[105] H. S. Azevedo and R. L. Reis, "Encapsulation of $\alpha$-amylase into starch-based biomaterials: an enzymatic approach to tailor their degradation rate," Acta Biomaterialia, vol. 5, no. 8, pp. 3021-3030, 2009.

[106] T. Itoh, R. Ish II, S. I. Matsuura et al., "Enhancement in thermal stability and resistance to denaturants of lipase encapsulated in mesoporous silica with alkyltrimethylammonium (CTAB)," Colloids and Surfaces B, vol. 75, no. 2, pp. 478-482, 2010.

[107] B. Wörsdörfer, K. J. Woycechowsky, and D. Hilvert, "Directed evolution of a protein container," Science, vol. 331, no. 6017, pp. 589-592, 2011.

[108] P. Cullinan, J. M. Harris, A. J. Newman Taylor et al., "An outbreak of asthma in a modern detergent factory," The Lancet, vol. 356, no. 9245, pp. 1899-1900, 2000.

[109] G. M. Liss, J. R. Kominsky, J. S. Gallagher, J. Melius, S. M. Brooks, and I. L. Bernstein, "Failure of enzyme encapsulation to prevent sensitization of workers in the dry bleach industry," Journal of Allergy and Clinical Immunology, vol. 73, no. 3, pp. 348-355, 1984.

[110] D. A. Basketter, C. Broekhuizen, M. Fieldsend et al., "Defining occupational and consumer exposure limits for enzyme protein respiratory allergens under REACH," Toxicology, vol. 268, no. 3, pp. 165-170, 2010.

[111] S. M. Tarlo and G. M. Liss, "Prevention of occupational asthma-practical implications for occupational physicians," Occupational Medicine, vol. 55, no. 8, pp. 588-594, 2005. 


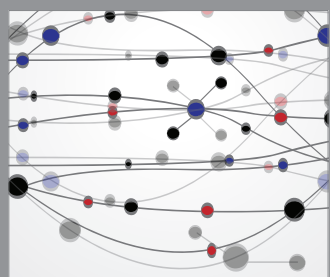

The Scientific World Journal
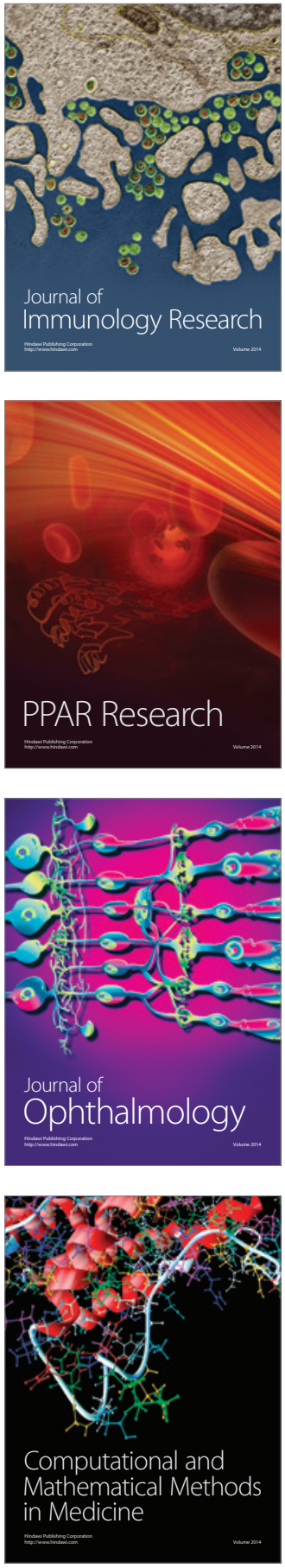

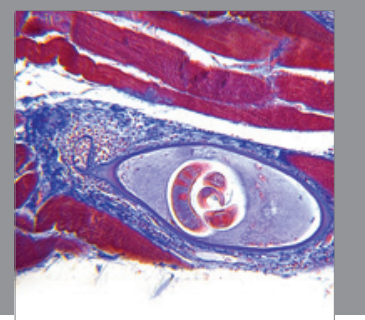

Gastroenterology

Research and Practice
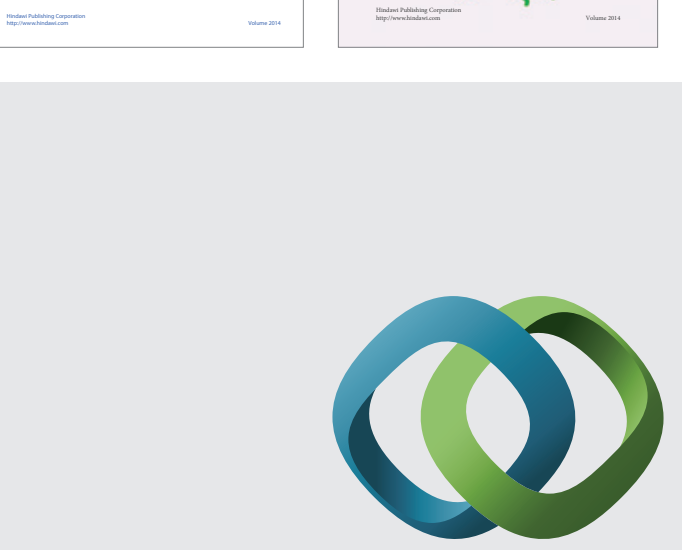

\section{Hindawi}

Submit your manuscripts at

http://www.hindawi.com
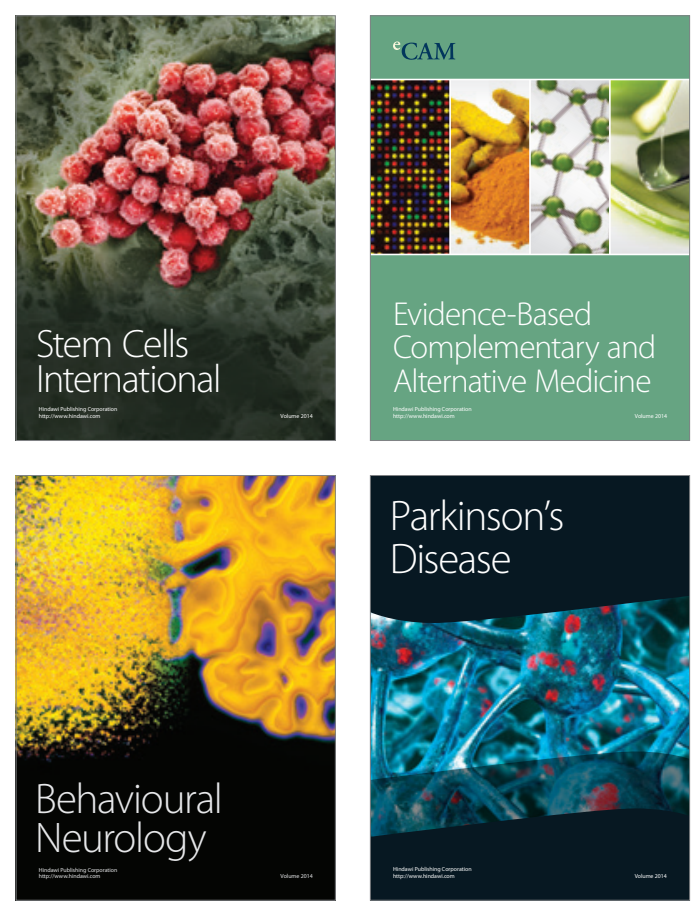

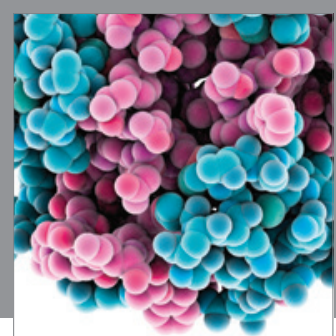

Journal of
Diabetes Research

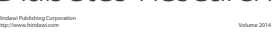

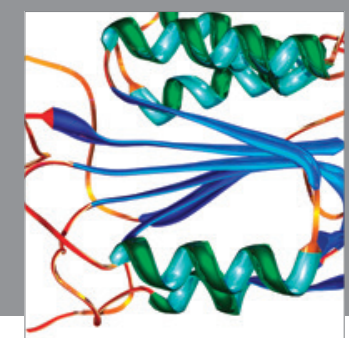

Disease Markers
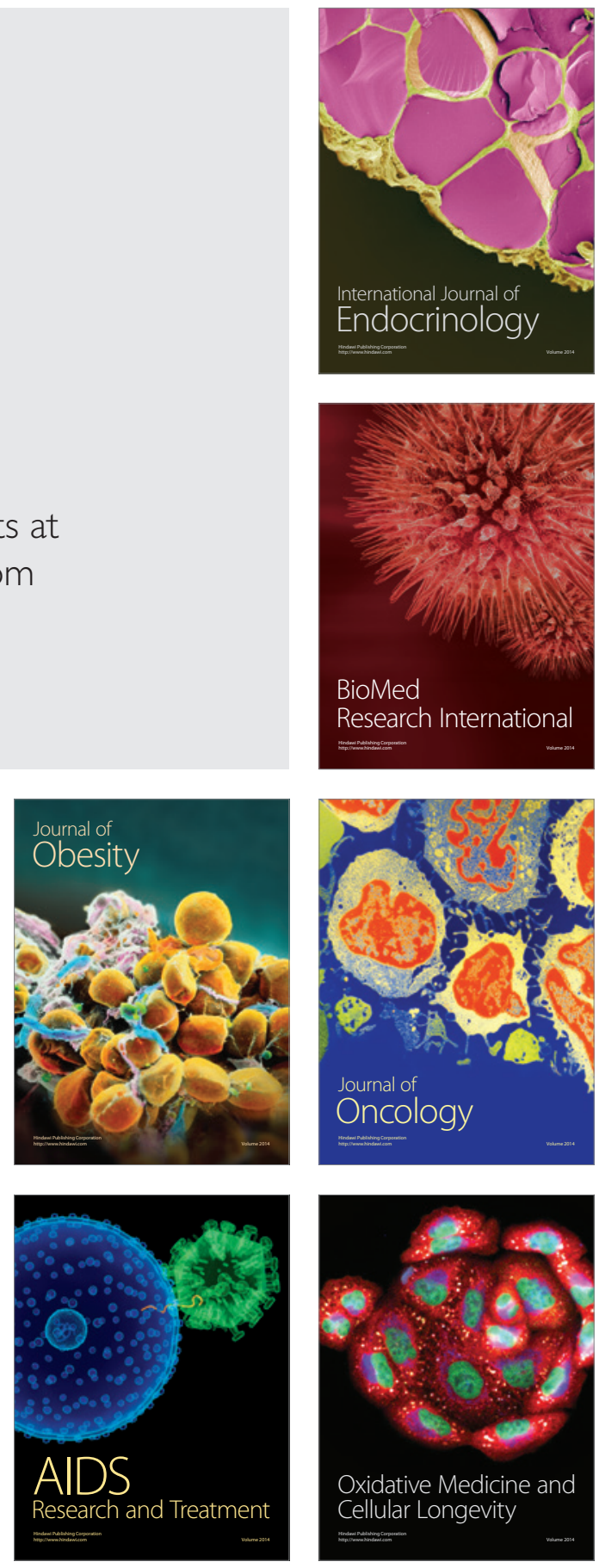